Louisiana State University

LSU Digital Commons

Faculty Publications

Department of Biological Sciences

$1-1-2004$

\title{
Variation in small sapling density, understory cover, and resource availability in four neotropical forests
}

Kyle E. Harms

Louisiana State University

Jennifer S. Powers

Stony Brook University

Rebecca A. Montgomery

University of Minnesota Twin Cities

Follow this and additional works at: https://digitalcommons.Isu.edu/biosci_pubs

\section{Recommended Citation}

Harms, K., Powers, J., \& Montgomery, R. (2004). Variation in small sapling density, understory cover, and resource availability in four neotropical forests. Biotropica, 36 (1), 40-51. https://doi.org/10.1111/

j.1744-7429.2004.tb00294.x

This Article is brought to you for free and open access by the Department of Biological Sciences at LSU Digital Commons. It has been accepted for inclusion in Faculty Publications by an authorized administrator of LSU Digital Commons. For more information, please contact ir@lsu.edu. 


\title{
Variation in Small Sapling Density, Understory Cover, and Resource Availability in Four Neotropical Forests ${ }^{1}$
}

\author{
Kyle E. Harms ${ }^{2}$ \\ Dept. of Biological Sciences, Louisiana State University, Baton Rouge, Louisiana 70803-1715, U.S.A.
}

Jennifer S. Powers

Dept. of Ecology and Evolution, SUNY-Stony Brook, Stony Brook, New York 11794-5245, U.S.A.

and

Rebecca A. Montgomery

Dept. of Forest Resources, College of Natural Resources, University of Minnesota, St. Paul, Minnesota 55414, U.S.A.

\begin{abstract}
Even though many forest plants spend all or a significant portion of their lives in the forest understory, few studies have compared understory composition, structure, and resource availability among forests. We used standardized transect-based methods to compare small sapling densities $(10-50 \mathrm{~cm}$ tall), understory vegetation cover, canopy openness, and nutrient availability in non-gap portions of four lowland Neotropical forests: La Selva, Costa Rica (LS), Barro Colorado Island, Panama (BCI), Cocha Cashu, Peru (CC), and north of Manaus, Brazil (KM41). Sites differed significantly in all variables except canopy openness. LS had high palm and non-fern herb cover and low density of small saplings $\left(0.7-1.6 / \mathrm{m}^{2}\right)$ compared to other sites. CC had high fern cover, whereas BCI had low cover in all categories of understory vegetation (palms, ferns, and non-fern herbaceous plants). BCI, CC, and KM41 had similar small sapling densities, ranging from $4.8-7.5 / \mathrm{m}^{2}$. Within each forest, cation $(\mathrm{Ca}, \mathrm{Mg}, \mathrm{K}$, and $\mathrm{Na}$ ) availability was usually higher on more fertile soil orders (Inceptisols, Alfisols, and Entisols) than on more weathered soil types (Ultisols and Oxisols). Extractable P was highest at LS and CC and lowest on BCI (no data for KM41). Spatial autocorrelation was present for some variables in some transects to distances beyond our detection ability $(>25 \mathrm{~m})$. Understory palm cover was negatively correlated with small sapling density at fine $\left(1 \mathrm{~m}^{2}\right.$ quadrat) and coarse spatial scales (among forests), although across forests the effect of palms was due entirely to the difference between $L S$ and the other three forests. These results provide cross-site support for the hypothesis that understory cover by palms decreases the density of small saplings that comprise the advance regeneration of the forest.
\end{abstract}

\section{RESUMEN}

Aunque muchas plantas del bosque pasan toda o una porción significativa de su vida en el sotobosque, pocos estudios han comparado la composición, la estructura, y la disponibilidad de recursos en el sotobosque entre bosques. Utilizamos los métodos estandardizados para comparar las densidades de plántulas (10-50 cm altura), la cobertura de vegetación del sotobosque, la abertura de dosel, y la disponibilidad de nutrientes en cuatro bosques Neotropicales de bajura: La Selva, Costa Rica (LS), Isla de Barro Colorado, Panamá (BCI), Cocha Cashu, Perú (CC), y al norte de Manaus, Brasil (KM41). Los sitios se diferenciaron significativamente en todas variables menos la abertura del dosel. LS presentó una cobertura de palmas y plantas herbáceas relativamente alta y una densidad baja de plántulas $\left(0.7-1.6 / \mathrm{m}^{2}\right)$ en comparación con otros sitios. CC presentó una cobertura alta de helechos, mientras que BCI tuvo una cobertura baja para todas las categorías de vegetación de sotobosque (palmas, helechos, y otras plantas herbáceas). BCI, CC, y KM41 presentaron densidades similares de plántulas, con un rango de $4.8-7.5 / \mathrm{m}^{2}$. Dentro de cada bosque, la disponibilidad de catión $(\mathrm{Ca}, \mathrm{Mg}, \mathrm{K}, \mathrm{y} \mathrm{Na})$ fue generalmente más alta en órdenes de suelos más fértiles (Inceptisols, Alfisols, y Entisols) que en suelos más viejos (Ultisols y Oxisols). Fósforo fue más alto en LS y CC, y menor en BCI (no hubo datos para KM41). Algunas variables presentaron autocorrelación espacial en algunos transectos a distancias mayores de nuestra habilidad de muestreo $(>25 \mathrm{~m})$. La cobertura de palmas en el sotobosque presentó una correlación negativa con respecto a la densidad de plántulas a la escala pequeña (cuadrantes de $1 \mathrm{~m}^{2}$ ) y a la escala espacial grande (entre bosques), sin embargo entre bosques el efecto de palmas se debió completamente a la diferencia entre LS y los otros tres sitios. Estos resultados apoyan la hipótesis que la cobertura de palmas en el sotobosque causa disminución en la densidad de plántulas, las cuales representan la regeneración avanzada del bosque.

Key words: forest understories; palms; regeneration; saplings; semivariograms.

${ }^{1}$ Received 5 November 2003; revision accepred 17 December 2003.

2 Corresponding author. e-mail: kharms@lsu.edu 
IN THEIR EFFORTS TO COMPARE AND CONTRAST ECOLOGICAL PATTERNS among tropical forests, Alwyn Gentry and colleagues collated data sets from four of the premier Neotropical field stations: La Selva (Costa Rica), Barro Colorado Island (Panama), Cocha Cashu (Peru), and the Biological Dynamics of Forest Fragments Project (Brazil) (Gentry 1990). Many useful observations were made in that landmark volume concerning similarities and differences among the four sites, but comparisons were based primarily on studies that lacked inter-site standardization. Hartshorn (1990), for example, lamented the lack of long-term standardized studies with which to compare forest diversity and dynamics among sites.

Forest dynamics research was largely focused on gap dynamics prior to Gentry (1990), and no explicit comparisons were made of understory conditions in that volume; however, the shaded understory is a staging area for the advance regeneration that establishes prior to gap formation (Uhl et al. 1988) and characteristics of the understory may influence the density and spatial patterns of woody seedlings, which in turn could contribute substantially to patterns of forest composition, structure, and dynamics (MacDougall \& Kellman 1992, Montgomery \& Chazdon 2001).

Only a small set of studies has used consistent methods to compare tropical understory conditions among sites that span countries or larger regions (Janzen 1977, Gentry \& Emmons 1987, Ruokolainen et al. 1997, Tuomisto \& Poulsen 2000). These studies have focused on abiotic conditions and plants that spend their entire life cycles in the understory. For such understory species, species density is positively related to rainfall, negatively related to seasonality, and positively (but less consistently) related to soil fertility (Gentry \& Emmons 1987, Wright 1992). Understory plant species composition also changes somewhat predictably as ferns and many non-fern herbaceous families are absent from the driest, most seasonal sites (Gentry \& Emmons 1987, Wright 1992).

To expand our geographically comparative understanding of both components of the understory vegetation (i.e., understory species and the understory stages of plants that later occupy higher strata), we used standardized methods to characterize the understory vegetation and the availability of selected resources within and among the four Neotropical lowland tropical forests highlighted by Gentry (1990). The four sites are all intact lowland forests at least 1500 ha in area. The sites differ in seasonality and soil fertility, thereby representing distinct alternative environmental conditions within the range that exists across the moist to wet Neotropical lowlands (Gentry 1990; Sombroek 2000,2001 ). We first present baseline data on soil cation and phosphorus availability, understory light levels, and vegetation characteristics. We then use these data to examine relationships among variables at a variety of spatial scales.

Plants in the understory are in severe asymmetric competition with overstory plants for light and soil-borne resources. Although experiments by Marquis et al. (1986) suggested that understory vegetation had no effect on seedling germination, other studies have shown that specific components of the understory vegetation may adversely affect regeneration. For example, Denslow et al. (1991) and Farris-Lopez et al. (in press) showed that understory palms and cyclanths can adversely affect regenerating woody dicots. In the temperate zone, ferns also have been shown to act as ecological filters to regeneration (George \& Bazzaz 1999a, b). Gentry and Emmons (1987) hypothesized that low light levels in the understory suppress understory plants and cause them to be particularly sensitive to drought and nutrient stress (Wright 1992). Taken together, these observations make it difficult to predict how both components of the understoryshort-statured plants and regenerating overstory plants-should vary with changes in physical conditions. Nevertheless, we hypothesized that the least stressful understory sites (i.e., those characterized by the least drought and nutrient stress) would have the highest cover values of plants that spend their lives in the understory and that small sapling densities would be inversely related to understory cover.

\section{MATERIALS AND METHODS}

Study sites and samplng scheme.-We sampled the vegetation and availability of selected resources within the understories of four Neotropical forests: La Selva Biological Station in Costa Rica (LS), Barro Colorado Island in Panama (BCI), Cocha Cashu Biological Station in Manu National Park, Peru (CC), and an area near the Kilometer 41 field camp of the Biological Dynamics of Forest Fragments Project north of Manaus, Brazil (KM41). Detailed site overviews can be found in Gentry (1990) and Powers (2004). Both LS and BCI were sampled midway through their wet seasons, whereas CC and KM41 were sampled at the beginning of their wet seasons. In all four forests, most deciduous trees were intercepting sunlight 
with fully leafed-out canopies at the time of our observations.

In each of the forests, we established three $1 \times$ $50 \mathrm{~m}$ transects on a less fertile soil order, and three transects on a more fertile soil order (described by Powers 2004). Transects avoided canopy gaps, were at least $200 \mathrm{~m}$ apart, and comprised 50 contiguous $1 \mathrm{~m}^{2}$ quadrats. We counted small saplings and estimated vegetation cover in every $1 \mathrm{~m}^{2}$ quadrat along each transect (300 quadrats/forest). We measured light availability in alternating quadrats ( 150 quadrats/forest). In addition, we sampled soil nutrient concentrations in 15 of the 24 transects (Powers \& Lerdau, pers. obs.).

SMALL SAPLINGs. - We counted all freestanding woody dicots with stems between 10 and $50 \mathrm{~cm}$ tall in each quadrat. This size class included relatively young plants but excluded most newly germinated seedlings. We further restricted our sample by excluding plants that retained their cotyledons. Although we encountered few plants $10-50 \mathrm{~cm}$ tall bearing cotyledons, excluding them decreased the chances of including newly germinated seedlings that are larger than $10 \mathrm{~cm}$ upon initial expansion. Newly germinated seedlings (i.e., plants $<10 \mathrm{~cm}$ tall or with cotyledons) were excluded to reduce the contributions of intra-annual or seasonal variation in first-year seedling recruitment to amongsite comparisons, since studies have shown that newly germinated seedling densities can be strongly related to seasonality, at least on BCI (Garwood 1982). We refer to the plants we sampled as "small saplings," as opposed to "seedlings."

UNDERSTORY COVER.-Within each quadrat, we estimated the percent cover from a $0.65 \mathrm{~m}$ height of non-sapling plants from the following three taxonomic or functional groups: palms (Arecaceae), ferns (Pteridophyta), and non-fern herbaceous plants (which included members of the following families: Araceae, Heliconiaceae, Marantaceae, Orchidaceae, Poaceae, Selaginellaceae, and Zingiberaceae). We recorded cover as the percent of a quadrat's $1 \mathrm{~m}^{2}$ area covered by the vertical projection onto the ground of plants from each taxonomic or functional group such that the total percent cover could not exceed 100 percent for any given group. Total projected area for each group was estimated by visual comparisons with reference objects of known area (i.e., plastic rectangles that could be held just above any portion of the quadrat).

LIGHT AVAILABILITY.- - Light availability was estimated by hemispherical photography using a Nikon
Coolpix 990 fitted with a fisheye lens. Photographs were taken at $0.65 \mathrm{~m}$, directly above the level of sapling and vegetation cover measurements every 2 $\mathrm{m}$ along the transects $(N=25 /$ transect $)$. Photos were analyzed using HemiView ver. 2 (Delta T Devices, Lrd.). For detailed methods and examination of patterns of light availability within and among the forests, see Montgomery (2004).

SOIL NUTRIENTS.-As part of a separate study, soils were collected from all six transects at both LS and $\mathrm{CC}$, and from three transects on BCI (two Oxisols and one Alfisol). We lack soil data for Brazil because it was not possible to export soils from that site. In each transect, five soil samples from the topsoil $(0-10 \mathrm{~cm})$ were bulked to yield a single sample per transect. Soil nutrient availability ( $\mathrm{P}$ and Mehlich III extractable cations [Ca, $\mathrm{Mg}, \mathrm{K}$, and Na]; Mehlich 1984) was measured using methods outlined in Powers et al. (2004).

Statistical analysis. - We characterized the patterns of understory vegetation and resources within and among the forests using (1) analysis of variance to document differences in average values; (2) coefficients of variation to characterize within-transect variability; (3) geostatistics to quantify spatial autocorrelation; (4) multiple linear regression to screen for predictors of small sapling density, followed by analysis of covariance (ANCOVA) with site as the main effect and the best predictor of small sapling density as the covariate; (5) Mantel tests to evaluate correlations between small sapling density and other variables within transects, after accounting for spatial autocorrelation; and (6) quantile regression to further evaluate relationships at the quadrat scale. Each of these analyses is described below.

Using analysis of variance, we evaluated among-forest differences in the mean and variation (measured as the coefficient of variation, i.e., $100^{*}$ [standard deviation/mean]) of small sapling density, percent cover of ground-layer vegetation, and light availability. We used transects as units of replication, and data were log transformed when required to normalize residuals. When sites differed significantly, Tukey's HSD tests for multiple comparisons were used to compare each pair of sites separately. Percent fern cover did not meet the homogeneity of variance assumption of ANOVA and data transformations did not remedy this. Therefore, for percent fern cover, we used a KruskalWallis test to evaluate site differences. Since there is no readily available post hoc multiple compari- 
son test to accompany the Kruskal-Wallis test, we conducted six pairwise comparisons with the Wilcoxon rank sum test and used the Bonferroni procedure to adjust significance levels. Within each forest, we used t-tests or Wilcoxon rank sum tests (if standard deviations differed by a factor of two between soil types) to compare small sapling densities, percent cover, and light availability on different soil types.

Using geostatistics, we quantified spatial autocorrelation for sufficiently sampled variables by calculating empirical variograms and then fitting models to the variograms using iterative procedures in SPLUS Spatial Stats (SPLUS 2000, MathSoft, Inc.). We fitted models only to empirical variograms that showed distinct spatial patterns. Alternative theoretical models (spherical, Gaussian, or linear) were fitted to empirical variograms; model fit was assessed by residual sums of squares; and the theoretical model providing the best fit was chosen. Variograms were calculated for small sapling density and cover variables for each transect using $2 \mathrm{~m}$ distance classes. We evaluated spatial pattern up to $25 \mathrm{~m}$, i.e., half the length of our transects (Kaluzny et al. 1998).

Three parameters estimated from a model variogram describe spatial autocorrelation in the data: (1) the range, which is the distance over which a variable is spatially autocorrelated and analogous to the "patch size"; (2) the sill or the asymptotic value of semi-variance at the range; and (3) the y-intercept or nugget variance, which describes sampling error or variation at distances less than those separating the closest pairs of samples. The semivariance will converge on total variance at distances for which values are no longer spatially autocorrelated. Thus, semivariance takes on values from 0 to the total variance in the data set (i.e., the upper limit of semi-variance values will depend upon the units of measurement). The percent structural variance is defined as the percentage of the total variation in the data attributed to spatial autocorrelation and is calculated as [(sill - nugget)/sill] ${ }^{*} 100$.

We used multiple linear regression to screen our quantitative variables (canopy openness, nutrient concentrations, and cover values of palms, ferns, and non-fern herbaceous plants) for significant predictors of small sapling density. Each transect was treated as a spatially independent sample in these analyses $(N=15$ including nutrients, and $N=24$ excluding nutrients), as justified by variogram analyses (see Results). We then used quantitative variables that were significant predictors of small sapling density as covariates in ANCOVAs to determine if their effects remained significant when considered together with forest (site) effects. For the ANCOVA models, site was the main effect and cover or resource variables were treated as covariates.

Within forests, we used Mantel tests to examine the relationships between small sapling density and cover values or canopy openness at the $1 \mathrm{~m}^{2}$ quadrat scale. Mantel tests assess the partial correlation between two variables (e.g., light availability and sapling density), after factoring out concordance due to spatial autocorrelation (Fortin \& Gurevitch 1993, Nicotra et al. 1999). Mantel tests were run in SPLUS using protocols suggested by Urban et al. (2002).

We further explored relationships among variables at the $1 \mathrm{~m}^{2}$ quadrat scale through quantile regression. Quantile regression assesses the homogeneity of slope within a bivariate scatterplot and can indicate factor-ceiling or threshold relationships when slopes differ among quantiles of the data set (Cade \& Noon 2003). We estimated 10th and 90th quantile slopes for small sapling density versus each of the cover variables and canopy openness using Blossom software (Cade \& Richards 1999).

\section{RESULTS}

Average Differences WithIN AND among forests.The four forests differed significantly in percent palm cover $\left(F_{3,20}=13.4, P<0.0001\right)$, percent fern cover (Kruskal-Wallis chi-square $=14.78, \mathrm{df}$ $=3, P=0.002)$, percent non-fern herbaceous cover $\left(F_{3,20}=13.8, P<0.0001\right)$, and small sapling density $\left(F_{3,20}=21.4, P<0.0001\right)$, but not canopy openness $\left(F_{3,20}=2.4, P=0.10\right)$. LS had more than twice the value of palm cover compared to the other three forests, and small sapling densities were roughly four times lower (Table 1). KM41 had significantly lower percent cover of both ferns and non-fern herbaceous plants than LS, $\mathrm{BCI}$, or $\mathrm{CC}$. Within sites, the only significant difference between soil types was at KM41, where the less fertile Spodosols had higher percent non-fern herbaceous cover than the Oxisols, although the difference was only 1 percent and unlikely to be biologically relevant. Absence of significant differences between soil types within sites justifies equally weighting transects for among-site comparisons.

The limited soil nutrient data suggest that differences among soil orders in cation availability are consistent with more "fertile" soil orders (Inceptisols, Alfisols, and Entisols) having higher values 


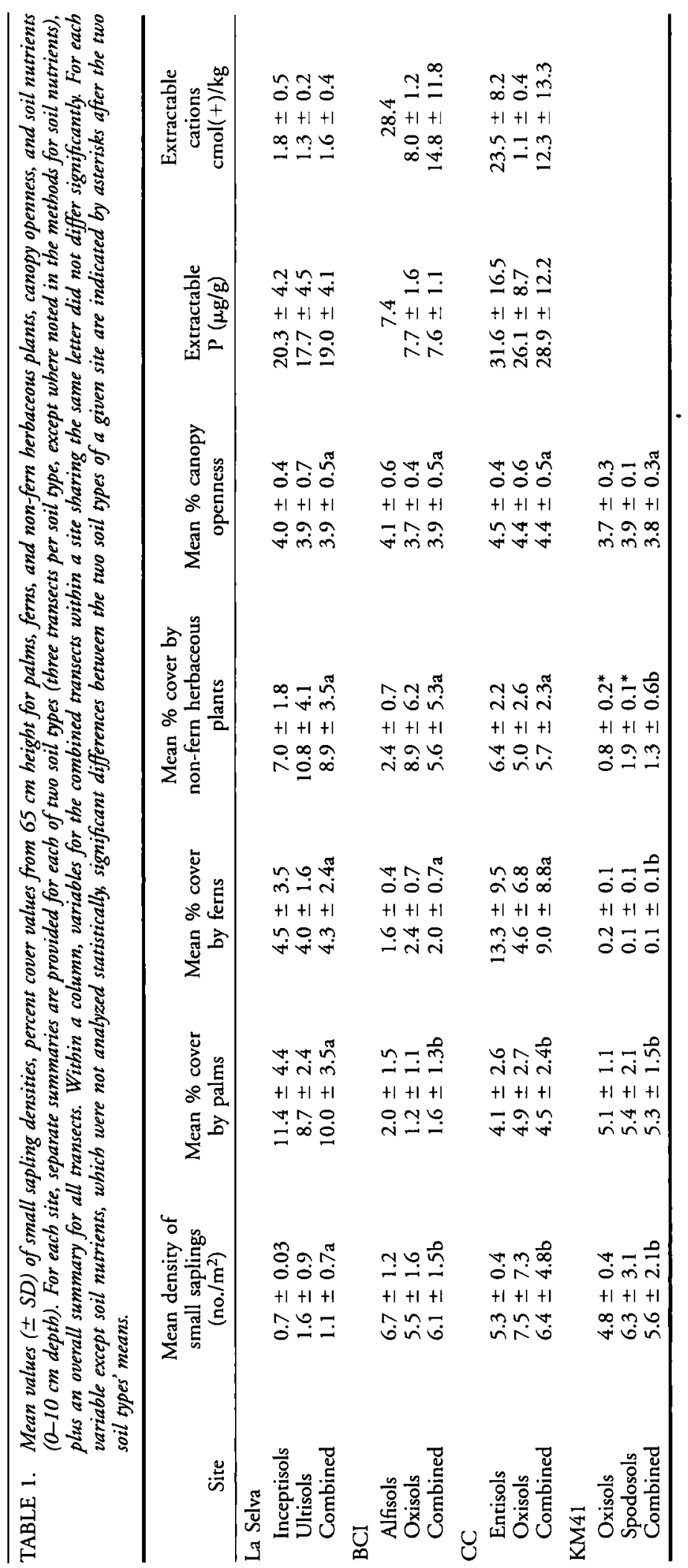



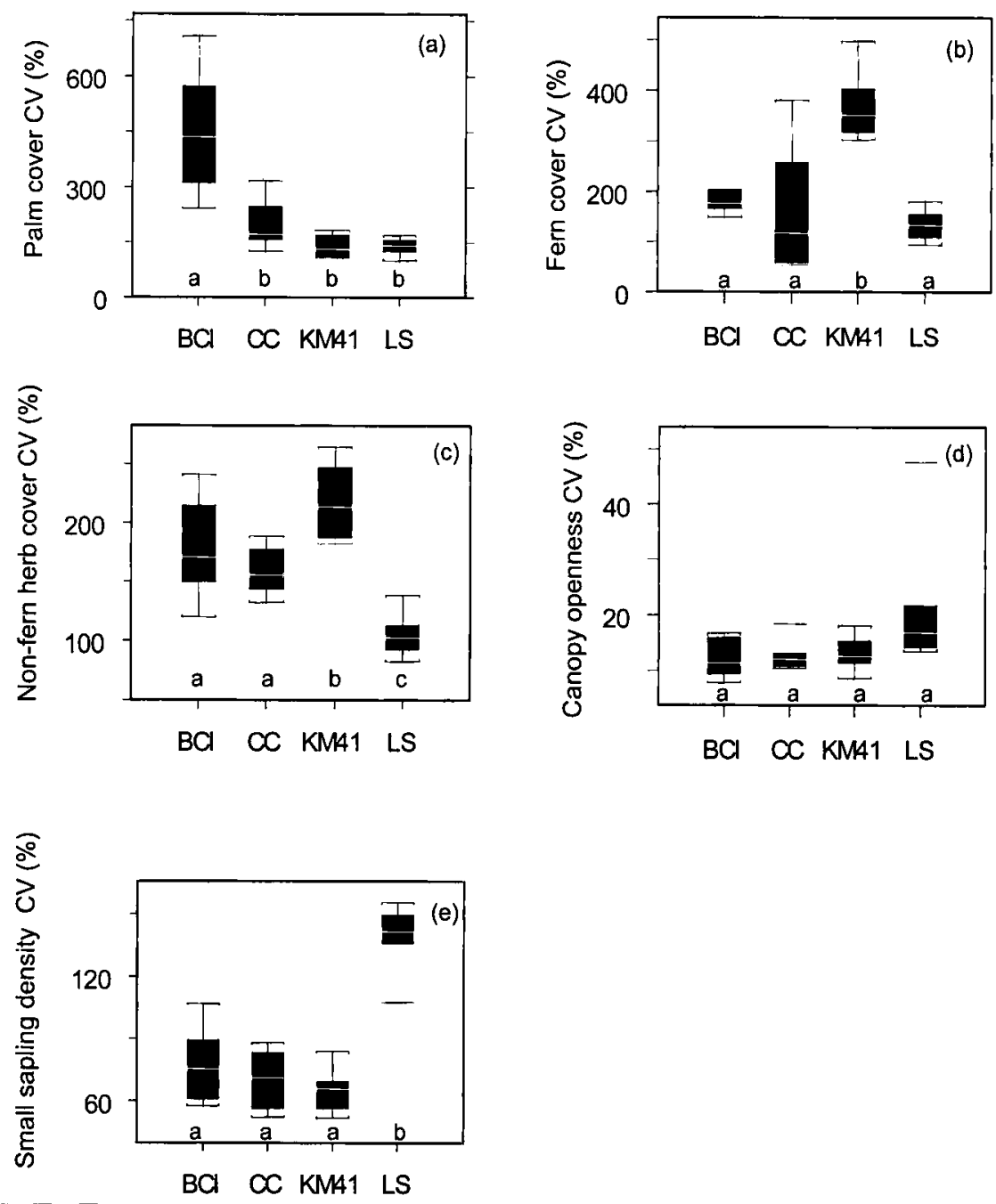

FIGURE 1. Box and whiskers plots for the coefficients of variation, grouped by site ( $N=6$ transects/site) for (a) understory palm percent cover, (b) understory fern percent cover, (c) understory non-fern herbaceous plant percent cover, (d) canopy openness, and (e) small sapling density. Sites sharing a letter (directly above site name) did not differ significantly from one another based on Tukey's mean separation tests.

than more weathered Ultisols and Oxisols at LS, $\mathrm{BCI}$, and CC (Table 1); however, no clear pattern relative to accepted "fertility" rankings was found for $\mathbf{P}$ availability (Table 1). Because our sampling scheme was nor proportional to the area-weighted distribution of different soil types, it is not appropriate to average measured soil nutrient concentrations within sites for among-site comparisons.

Patterns of VARIABILITY AMONG FORESTs. - Withintransect coefficients of variation (CV) for percent cover of understory vegetation ranged from 53.4 to 708 percent, whereas CVs for canopy openness were considerably lower (range $=7.8-47.7 \%$ ). Small sapling density had intermediate CVs (range $=52-156 \%$ ).

Patterns of variability differed among forests (Fig. 1). BCI had significantly higher variation in palm cover $\left(F_{3,20}=18.90, P<0.0001\right)$ compared to the other sites. For fern cover, KM41 had significantly higher variation $\left(F_{3,19}=9.85, P<\right.$ $0.0004)$ than the other sites. KM41 had the highest mean $\mathrm{CV}$ for non-fern herbaceous cover, LS had the lowest, and $\mathrm{BCI}$ and $\mathrm{CC}$ had intermediate values for mean CVs $\left(F_{3,20}=13.35, P<0.0001\right)$. Coefficients of variation for canopy openness did 
not differ significantly among sites $\left(F_{3,20}=2.45\right.$, $P=0.09)$. Finally, LS had significantly higher mean $\mathrm{CV}$ for small sapling density compared to all other sites $\left(F_{3,20}=27.95, P \ll 0.0001\right)$. In general, the differences in CVs among sites were negatively related to mean values; sites with higher mean values had lower CVs for the same variable (Table 1 and Fig. 1).

Patterns of SPatial autocorrelation WITHIN ForESTS.-Three different patterns were revealed in the variogram analyses (Fig. 2): (1) no spatial pattern in a particular variable, such as small sapling density in transect 3 at LS (Fig. 2a); (2) spatial autocorrelation in a particular variable with a range less than half the length of the transect, such as small sapling density in transect 6 at KM41 (Fig. 2b); or (3) spatial autocorrelation to distances beyond half the length of the transect (Fig. 2c). In the third case, linear models provided the best fits, and it was not possible to estimate range distances or sills.

At both LS and CC, the spatial distribution of small saplings was autocorrelated at only one out of the six transects, and the range distances were short (Table 2). Small sapling density was autocorrelated in five of the six transects at both $\mathrm{BCI}$ and $\mathrm{KM} 41$, with the mean range distances being longer at $\mathrm{KM} 41(17 \mathrm{~m})$ than $\mathrm{BCI}(11.6 \mathrm{~m})$. When palm cover was autocorrelated, the range distances were generally short (Table 2). In contrast, when nonfern herbaceous cover was autocorrelated, the range distances were often $>25 \mathrm{~m}$, as indicated by linear models fit to the empirical variograms. There were no cases of spatial autocorrelation for fern cover. For the variable-transect combinations in which autocorrelation was detected, spatial variation explained from 33 to 99 percent of the variation (Table 2).

SMALL SAPLING DENSITY RELATIVE TO RESOURCES AND GROUND-LAYER VEGETATION AMONG FORESTS.-USing transects as sample units, the regression analysis that included all cover variables and light explained a modest amount of the variation in small sapling density $\left(R^{2}=0.17, P=0.044, F_{1,22}=4.56\right)$, and only mean cover by palms was a significant $(P$ $=0.007)$ determinant of the density of small saplings (Fig. 3). As palm cover increased, small sapling density decreased. The fit of this model was substantially increased by omitting one transect from CC with very high small sapling density $\left(R^{2}\right.$ $\left.=0.47, P=0.002, F_{2,20}=8.88\right)$, and in this model both palm cover $(P=0.003)$ and non-fern herbaceous cover $(P=0.055)$ explained a portion (a) Small sapling density - La Selva

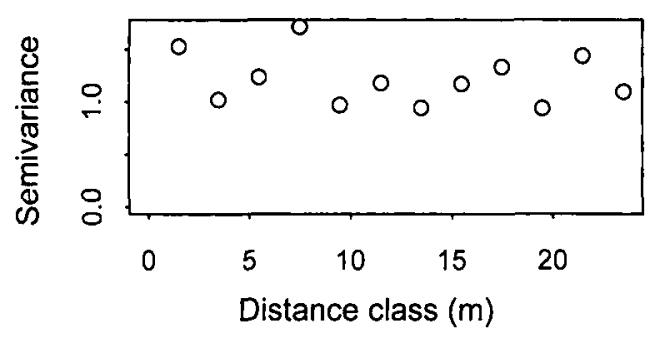

(b) Small sapling density - KM41

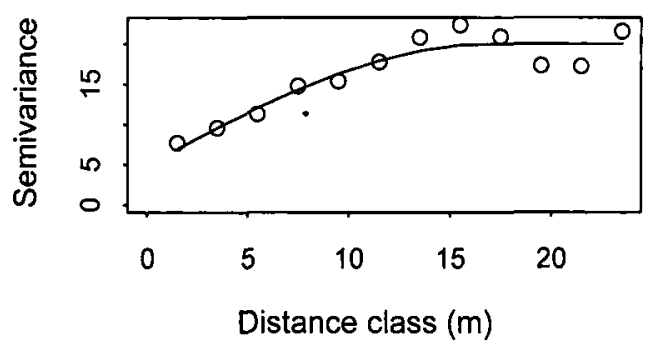

(c) Non-fern herb cover - Cocha Cashu

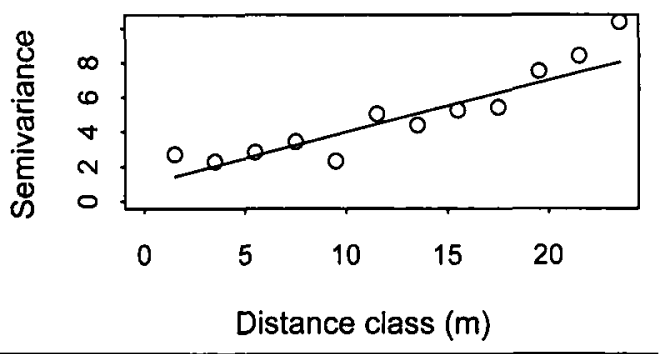

FIGURE 2. Examples of spatial patterns revealed by semivariograms: (a) no spatial dependence of small sapling density at LS, (b) spatial autocorrelation of small sapling density at KM41, at least out to the lag distance at which the fitted curve asymptotes, and (c) linear trend over the length of the transects for non-fern herbaceous cover at CC.

of the variation in small sapling densities across sites. Careful inspection, however, of the relationship between palm cover and small sapling densities (Fig. 3) suggests that this relationship may not hold within sites, especially at LS, where there was no apparent relationship, and at KM41, where the relationship appeared to be positive. An ANCOVA with site (forest) as the main effect and percent palm cover as a covariate showed a significant effect of site $(P=0.019)$ but no effect of percent palm cover $(P=0.52)$ or site $\times$ palm cover interaction $(P=0.63)$. 


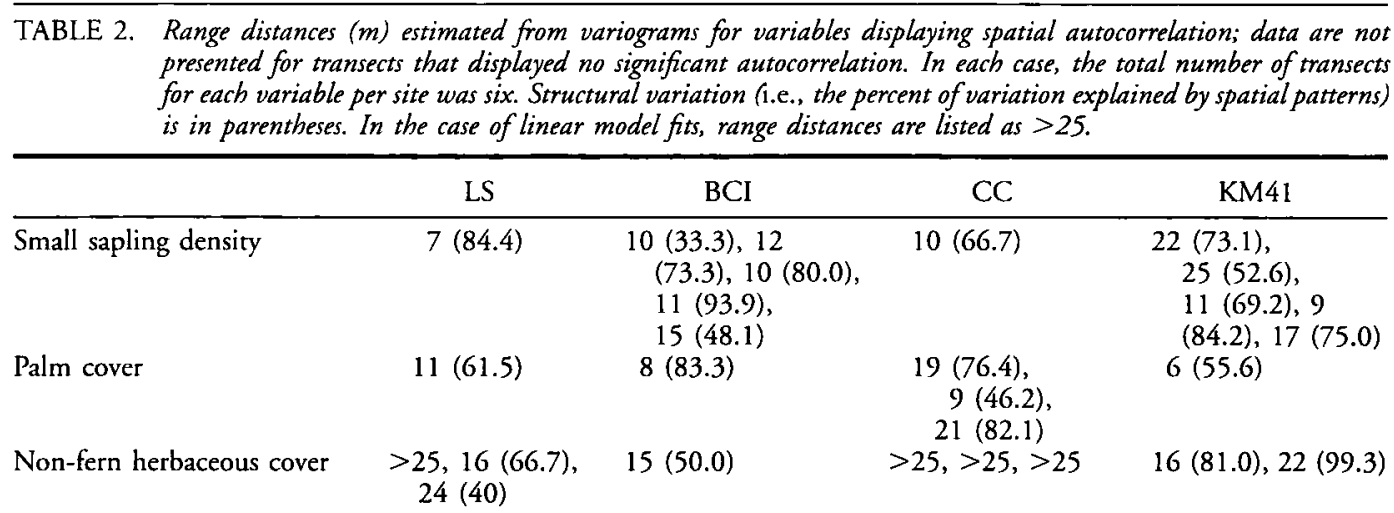

Scatterplots of small sapling density or palm cover as a function of soil nutrient concentrations suggest that there may be nonlinear relationships among these variables, which could go undetected in linear regression (Fig. 4). Across forests, percent palm cover was unimodally related to soil $P$ levels. At low cation availability, palm cover was variable but was always low on soils with higher cation concentrations (Fig. 4). In contrast, with the exception of a single transect with high sapling densities at $\mathrm{CC}$, sapling densities were higher at low or high soil $P$ and low on soils with intermediate soil $P$. Across forests, sapling densities increased with increasing cation concentrations.

SMall SAPLing Density Relative to resources and GROUND-LAYER VEGETATION AT THE QUADRAT SCALE WITHIN FORESTS. - Mantel tests revealed few significant relationships between small sapling density

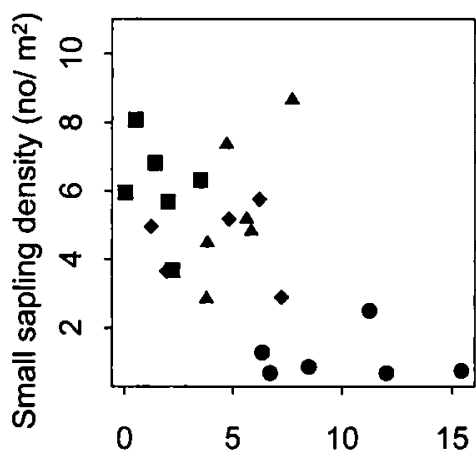

Percent palm cover

FIGURE 3. Small sapling density versus percent palm cover in 24 transects from four Neotropical forests. Symbols are as follows: squares (BCI), triangles (KM41), diamonds (CC), and circles (LS). and canopy openness or percent cover values for understory vegetation (Table 3). At each site, only 2 or 3 of the 18 variable-transect combinations showed significant relationships for cover variables. The 10 significant relationships were all positive, with 1 for palm cover, 4 for fern cover, and 5 for non-fern herbaceous cover. No transect displayed a significant relationship with more than one cover variable. Canopy openness was not significantly related to small sapling density in any transect at any site.

Mantel tests are inadequate for detecting nonlinear, factor-ceiling, or threshold relationships. In contrast, quantile regression using quadrats as the sample unit demonstrated such relationships between small sapling density and all three understory percent cover variables (Fig. 5). The 10th and 90 th quantile regression slopes, respectively, were as follows for all quadrats combined $(N=1200)$ : palm cover, $0.00,-0.15$; fern cover, $0.00,-0.16$; and non-fern herbaceous cover, $0.00,-0.12$. For all three cover variables, the 90 th quantile regression slopes were significantly different from 0.00 . In contrast, neither the 10th nor 90th quantile regression slopes differed from 0.00 for the relationship between small sapling density and canopy openness. When quadrats for each forest were analyzed separately, we found qualitatively similar factor-ceiling relationships between palm cover and sapling density (i.e., the shapes of the bivariate distributions were similar even though the slopes of the 90th quantiles were not exactly the same).

\section{DISCUSSION}

VARIATION IN MEANS AND SPATIAL PATTERNS WITHIN AND AMONG FORESTS.-We found striking differences in forest understory composition, nutrient avail- 

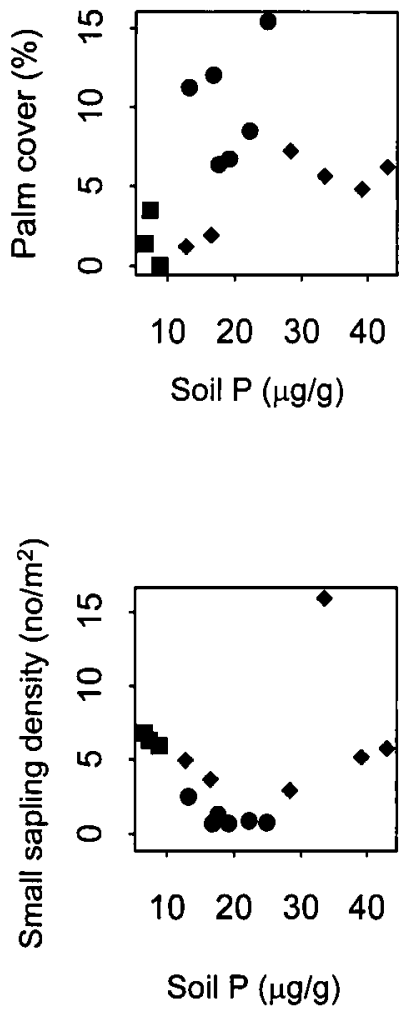

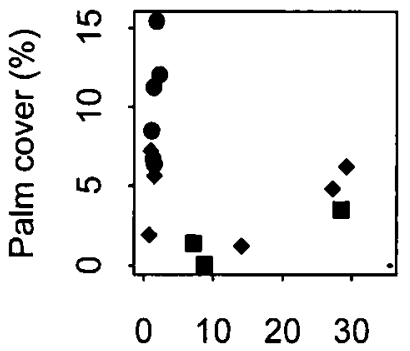

Extractable cations $(\mathrm{cmol}+/ \mathrm{kg})$

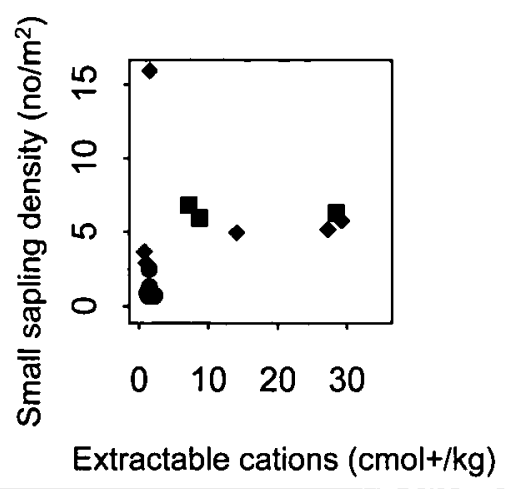

FIGURE 4. Percent palm cover and small sapling densities as a function of Mehlich III extractable P and cations. Symbols are as in Figure 3.

ability, and sapling density among four Neotropical forests. Most notably, LS- the least seasonal and most fertile site-differed strongly from all other sites in its low density of small saplings and high cover of understory palm and herbaceous vegetation. CC had high fern cover, the understories of $\mathrm{BCI}$ and KM41 were comparatively open, and all three of these sites had similar mean densities of small saplings (Table 1). Our results support the hypotheses of Gentry and Emmons (1987) and Janzen (1977) that predict declines in biomass of understory vegetation with drier, more seasonal and more nutrient-poor conditions. Our data are also consistent with our initial prediction that regenerating saplings at sites with less stressful physical environments (i.e., high aseasonal rainfall and relatively high nutrient availability) may face greater competition from increased densities of understory vegetation; however, the apparent non-linear relationships between nutrient concentrations and both palm cover and sapling densities suggest that these relationships may be complex (Fig. 4). The conspicuous absence of variation in canopy openness at $0.65 \mathrm{~m}$ may result primarily from position- ing transects to avoid gaps; i.e., gap size, frequency and spatial arrangement may differ among sites. In addition, the forests differ in the vertical distribution of light availability (Montgomery 2004), which could influence variation in understory vegetation among sites.

In addition to differences in the average values of most understory variables, sites differed in the patterns of variation or heterogeneity in understory plant cover, such that the probability of encountering a particular patch type within a site varied among forests. Thus, the forests differ in the typical environment seedlings and saplings experience. For example, the likelihood that a seedling establishing in the understory at LS is covered by an understory palm is higher and more constant throughout the forest than compared to a seedling establishing on BCI (Table 1 and Fig. 1). BCI had low cover of palms but high $C V$, suggesting that palms occurred in patches within a relatively palm-free landscape. Autocorrelation of saplings, especially at BCI and KM41 where saplings were clumped in most transects (Table 2), was not clearly related to spatial parterning of understory vegetation cover (i.e., veg- 
TABLE 3. Partial Mantel coefficients for small sapling densities relative to understory vegetation cover and canopy openness, after accounting for spatial autocorrelation. One-sided $\mathrm{P}$-values are in parentheses, and $\mathrm{P}$-values $\leq 0.05$ are in bold.

\begin{tabular}{|c|c|c|c|c|c|c|c|}
\hline \multirow{2}{*}{$\frac{\text { Transect }}{\text { LS-1 }}$} & \multicolumn{2}{|c|}{ Palm cover $(\%)$} & \multicolumn{2}{|c|}{ Fern cover (\%) } & \multirow{2}{*}{$\begin{array}{c}\begin{array}{c}\text { Non-fern herbaceous } \\
\text { cover }(\%)\end{array} \\
0.01(0.29)\end{array}$} & \multicolumn{2}{|c|}{$\begin{array}{c}\text { Canopy } \\
\text { openness (\%) }\end{array}$} \\
\hline & -0.03 & $(0.50)$ & 0.12 & $(0.11)$ & & -0.15 & $(0.92)$ \\
\hline LS-2 & -0.02 & $(0.44)$ & -0.05 & $(0.62)$ & $-0.04(0.66)$ & -0.13 & $(0.95)$ \\
\hline LS-3 & -0.01 & $(0.41)$ & -0.04 & $(0.58)$ & $-0.06(0.74)$ & -0.03 & $(0.55)$ \\
\hline LS-4 & -0.04 & $(0.58)$ & 0.34 & $(\mathbf{0 . 0 0 )}$ & $-0.04(0.64)$ & -0.04 & $(0.44)$ \\
\hline LS-5 & 0.23 & $(0.04)$ & -0.08 & $(0.80)$ & $-0.06(0.79)$ & -0.13 & $(0.89)$ \\
\hline LS-6 & -0.03 & $(0.44)$ & -0.09 & $(0.98)$ & $0.14(0.03)$ & -0.14 & $(0.97)$ \\
\hline BCI-1 & -0.08 & $(0.93)$ & -0.04 & $(0.68)$ & $0.18(0.02)$ & -0.15 & $(0.96)$ \\
\hline $\mathrm{BCI}-2$ & -0.02 & $(0.48)$ & 0.06 & $(0.25)$ & $0.11(0.08)$ & 0.09 & $(0.19)$ \\
\hline BCI-3 & -0.07 & $(0.74)$ & 0.19 & $(0.02)$ & $0.07(0.21)$ & 0.12 & $(0.11)$ \\
\hline $\mathrm{BCl}-4$ & -0.03 & $(0.46)$ & -0.11 & $(0.95)$ & $0.10(0.15)$ & -0.04 & $(0.55)$ \\
\hline $\mathrm{BCI}-5$ & 0.001 & $(0.42)$ & -0.06 & $(0.73)$ & $0.17(0.05)$ & -0.11 & $(0.83)$ \\
\hline BCI-6 & 0.001 & $(0.45)$ & -0.10 & $(0.92)$ & $-0.11(0.95)$ & -0.003 & $(0.42)$ \\
\hline CC-1 & 0.04 & $(0.24)$ & 0.10 & $(0.13)$ & $0.15(0.06)$ & -0.04 & $(0.63)$ \\
\hline $\mathrm{CC}-2$ & -0.008 & $(0.51)$ & 0.20 & $(0.02)$ & $-0.03(0.60)$ & -0.05 & $(0.71)$ \\
\hline $\mathrm{CC}-3$ & -0.02 & $(0.57)$ & 0.02 & $(0.34)$ & $0.04(0.24)$ & 0.05 & $(0.22)$ \\
\hline$C C-4$ & 0.03 & $(0.31)$ & 0.19 & $(0.04)$ & $0.06(0.21)$ & -0.08 & $(0.69)$ \\
\hline CC-5 & 0.07 & $(0.19)$ & 0.03 & $(0.25)$ & $0.07(0.17)$ & -0.13 & $(0.93)$ \\
\hline CC- 6 & 0.02 & $(0.33)$ & -0.08 & $(0.89)$ & $-0.07(0.85)$ & -0.02 & $(0.59)$ \\
\hline KM41-1 & -0.08 & $(0.94)$ & -0.004 & $(0.32)$ & $-0.09(0.81)$ & 0.08 & $(0.16)$ \\
\hline KM41-2 & 0.06 & $(0.21)$ & -0.07 & $(0.76)$ & $0.38(0.02)$ & 0.03 & $(0.31)$ \\
\hline KM41-3 & -0.03 & $(0.49)$ & * & & $0.20(0.05)$ & -0.12 & $(0.89)$ \\
\hline KM41-4 & -0.03 & $(0.51)$ & -0.02 & $(0.43)$ & $0.05(0.24)$ & -0.07 & $(0.78)$ \\
\hline KM41-5 & 0.07 & $(0.18)$ & -0.08 & $(0.83)$ & $-0.12(0.96)$ & -0.06 & $(0.69)$ \\
\hline KM41-6 & 0.05 & $(0.23)$ & -0.02 & $(0.46)$ & $-0.04(0.55)$ & 0.08 & $(0.22)$ \\
\hline
\end{tabular}

* No fern cover in this transect.

etation cover was rarely autocorrelated at these sites).

THE IMPORTANCE OF PALMS.--Despite the fact that our sapling counts included different species and life-forms (e.g., canopy and understory trees, lianas,

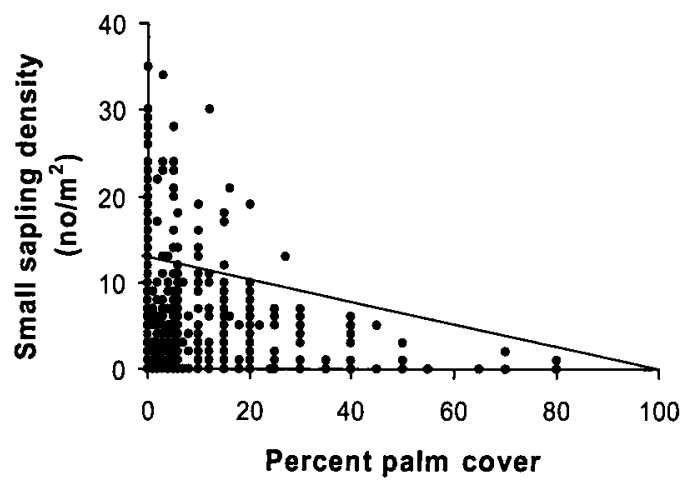

FIGURE 5. Small sapling density versus percent palm cover in $12001 \mathrm{~m}^{2}$ quadrats from four Neotropical forests. Tenth and 90th quantile regression slopes are plotted as solid lines; the 90 th quantile regression slope lies along the $x$-axis. and shrubs), palm cover was related to variation in small sapling density at fine $\left(1 \mathrm{~m}^{2}\right.$ quadrat $)$ and coarse (among forests) spatial scales. At the $1 \mathrm{~m}^{2}$ scale, quantile regression showed that palm cover created a boundary condition for small sapling density, such that when palm cover was low, small sapling densities could be either low or high, but when palm cover was high, small sapling densities were always low (Fig. 5). This relationship occurred across all forests as well as within any given forest. At the among-forest scale across these four forests, there was also a negative relationship between palm cover and small sapling density. This overall pattern emerged when transects from multiple forests that encompass large variation in both palm and sapling densities were included. In contrast, at the intermediate, within-forest scale sampled with $50 \mathrm{~m}$ transect means, there was apparently no relationship between palm cover and small sapling density (Fig. 3). There may have been insufficient variation in either variable when means were taken for transects and compared within a given forest. Factorceiling relationships between palm cover and small sapling density at the quadrat scale within a site support this explanation. It is also likely that un- 
derstory vegetation above $65 \mathrm{~cm}$, which would have been missed by our sampling design, influences the regeneration of woody dicots. A recent study at LS confirmed the negative effect that dwarf palms and cyclanths, including individuals above $1 \mathrm{~m}$, have on woody seedling recruitment (Wang \& Ausgpurger, pers. comm).

Palm cover may influence small sapling abundance through several potential mechanisms. Understory palms may compete with regenerating seedlings and small saplings for space, nutrients, water, or light. For example, understory vegetation, including small palms, can attenuate light as it passes from the canopy to the forest floor, thereby eliminating a direct relationship between the seedling layer and light penetration through the overstory canopy (Montgomery 2004). This may explain why we observed no direct relationship between canopy openness at $65 \mathrm{~cm}$ height and small sapling density. Palms may also provide habitat to herbivores and pathogens that cause elevated stem damage and mortality to regenerating plants in their vicinity (Denslow et al. 1991).

Other processes yielding negative relationships between palm cover and seedling and sapling density include decreased seed deposition, increased seed predation beneath understory palms, differences in microclimate, and increased mechanical damage. Farris-Lopez et al. (in press) showed that palms not only influence seedlings by decreasing light, but also by increasing litter under their canopies. Both factors caused decreases in seedling density and species richness. Species with large seeds and disease resistance were favored under palms (Farris-Lopez et al., in press). Irrespective of the particular mechanisms, the patterns that we found suggest that understory palms may effectively alter the pattern of regeneration by overstory plants, thereby uncoupling the direct relationship between conditions imposed by the forest canopy and the density of small saplings below.

Conclusions. - Despite the short duration of our study and the fact that it was limited to non-gap portions of the forest understory, the use of common methods allowed direct comparison among these four forests. The differences in the mean levels of understory plant cover and soil ferrility, as well as the variation in these factors, may have consequences for forest dynamics. For example, small sapling densities were spatially autocorrelated at $\mathrm{BCl}$ and $\mathrm{KM} 41$, but not at $\mathrm{LS}$ and $\mathrm{CC}$. This suggests that dispersal or post-establishment processes, such as differential growth or mortality in response to resource parches, may be responsible for clumped saplings at $\mathrm{BCI}$ and $\mathrm{KM} 41$, and that these processes are less important in the other forests. The tantalizing patterns we found demonstrate that all tropical forest understories are not created equal. Future studies that use a geographically comparative approach are needed to understand the causes of these patterns and the consequences for forest dynamics.

\section{ACKNOWLEDGMENTS}

We thank OTS for providing the opportunity to conduct this study; everyone associated with OTS 25-2001 for their valued contributions to this study and to the broader four-forests experience; Barry Moser for post-course statistical advice; and D. Urban for providing SPLUS code for the Mantel tests. P. Tiffin and S. DeWalt provided many helpful comments on previous drafts. Reviews by $\mathrm{R}$. Chazdon, J. Wright, and C. Vriesendorp greatly improved the manuscript. JSP thanks the Graduate Women in Science for funding. RAM thanks the Hilldale Committee at the University of Wisconsin-Madison for funding.

\section{LITERATURE CITED}

CADE, B. S. AND B. R. NoON. 2003. A gentle introduction to quantile regression for ecologists. Front. Ecol. Environ. 1: $412-420$.

, AND J. Richards. 1999. User manual for Blossom statistical software. U.S. Geoolgical Survey, Fort Collins, Colorado, $107 \mathrm{pp}$.

Denslow, J. S., E. Newel.l, and A. M. Ellison. 1991. The effect of understory palms and cyclanths on the growth and survival of Inga seedlings. Biotropica 23: 225-234.

Farris-Lopez, K., J. S. Denslow, B. Moser and H. Passmore. 2004. Influence of a common palm, Oenocarpus mapora, on seedling establishment in a tropical moist forest in Panama. J. Trop. Ecol. In press.

Fortin, M.-J., AND J. Gurevirch. 1993. Mantel tests: Spatial structure in field experiments. In S. M. Scheiner and Jessica Gurevitch (Eds.). Design and analysis of ecological experiments, pp. 308-326. Oxford University Press, Oxford, England.

Garwood, N. C. 1982. Seasonal rhythm of seed germination in a semideciduous tropical forest. In E. G. Leigh Jr., A. S. Rand, and D. M. Windsor (Eds.). The ecology of a tropical forest, pp. 173-185. Smithsonian Institution Press, Washington, DC.

Gentry, A. H. (ED.). 1990. Four Neotropical rainforests. Yale University Press, New Haven, Connecticut. 
-, AND L. H. EMmons. 1987. Geographical variation in fertility, phenology, and composition of the understory of Neotropical forests. Biotropica 19: 216-227.

George, L. O., AND F. A. Bazzaz. 1999a. The fern understory as an ecological filter: Emergence and establishment of canopy-tree seedlings. Ecology 80: 833-845.

—_ AND - 1999b. The fern understory as an ecological filter: Growth and survival of canopy-tree seedlings. Ecology 80: 846-856.

Hartshorn, G. S. 1990. An overview of Neotropical forest dynamics. In A. H. Gentry, (Ed.). Four Neotropical rainforests, pp. 585-599. Yale University Press, New Haven, Connecticut.

Janzen, D. H. 1977. Promising directions of study in tropical animal-plant interactions. Ann. Mo. Bot. Gard. 64: $706-736$

Kaluzny, S. P., S. C. Vega, T. P. Cardoso, and A. A. Shei.ly. 1998. Splus Spatial Stats. Springer, New York, New York.

MacDougall, A., and M. Kellman. 1992. The understory light regime and patterns of tree seedlings in tropical riparian forest patches. J. Biogeogr. 19: 667-675.

Marquis, R. J., H. J. Young, ANd H. E. BAKer. 1986. The influence of understory vegetation cover on germination and seedling establishment in a tropical lowland wer forest. Biotropica 18: 273-278.

Mehlich, A. 1984. Mehlich 3 soil test extractant: A modification of the Mehlich 2 extractant. Comm. Soil Plant Anal. 15: 1409-1416.

Montgomerv, R. A. 2004. Effects of understory vegetation on patterns of light attenuation near the forest floor. Biotropica 36: 33-39.

forests. Ecology 82: 2707-2718.

Nicotra, A. B., R. L. Chazdon, and S. V. B. Iriarte. 1999. Spatial heterogeneity of light and woody seedling regeneration in tropical wet forests. Ecology 80: 1908-1926.

Powers, J. S. 2004. New perspectives in comparative ecology of Neotropical rain forests. Biotropica 36(1): 2-6.

- M. H. Kalicin, and M. E. Newman. 2004. Tree species do not influence local soil chemistry in a speciesrich Costa Rican rain forest. J. Trop. Ecol. In press.

Ruokolainen, K., A. Linna, and H. Tuomisto. 1997. Use of Melastomataceae and pteridophytes for revealing phytogeographic patterns in Amazonian rain forests. J. Trop. Ecol. 13: 243-256.

Sombroek, W. 2000. Amazon landforms and soils in relation to biological diversity. Acta Amazonica 30: 81-100.

Sombroek, W. 2001. Spatial and temporal patterns of Amazon rainfall. Ambio 30: 388-396.

Tuomisto, H., and A. D. Poulsen. 2000. Pteridophyte diversity and species composition in four Amazonian rain forests. J. Veg. Sci. 11: 383-396.

Uhl, C., K. Clark, N. Dezzeo, and P. Maquirino. 1988. Vegetation dynamics in Amazonian treefall gaps. Ecology 69: 751-763.

Urban, D., S. Goslee, K. Pierce, and T. Lookingbill. 2002. Extending community ecology to landscapes. Ecoscience 9: 200-212.

WRIGHT, S. J. 1992. Seasonal drought, soil fertility, and the species diversity of tropical forest plant communities. Trends Ecol. Evol. 7: 260-263. 